\title{
Preparation of Sucrose Complexes of Chromium and the Study of their Viability as Food Supplement for Chromium Deficiency
}

\author{
ANITA K GUPTA $^{1^{*}}$ and HARI OM PANDEY ${ }^{2}$ \\ ${ }^{1}$ Department of Chemistry, S.S. Memorial College, Kanke Road, Ranchi, Jharkhand, India \\ ${ }^{2}$ Department of Chemistry, Ranchi University, Ranchi, Jharkhand, India \\ guptaanitak@yahoo.in
}

Received 28 January 2014 / Accepted 20 February 2014

\begin{abstract}
Chromium(III) is biologically active ingredient of food and is known to enhance the action of insulin, a hormone critical to metabolism and storage of carbohydrate, fat and protein in body. On the other hand, chromium(VI) is toxic substance in any form. Chromium deficiency may be cured by commercially available food supplements like chromium picolinate and chromium polynicotinate. In the present work, we report the method of preparation and characterization of products formed by the interaction of di-tertiary butyl chromate with sucrose in order to explore whether the products containing chromium(III) in combination with oxidised products of sucrose can be used as food supplement for chromium deficiency.
\end{abstract}

Keywords: Sucrose, Microwave, Ditertiary butyl chromate, Chromium food supplement

\section{Introduction}

Toxic chromium(VI) can be reduced to beneficial chromium(III) by the reaction with organic substrates. Chromium picolinate ${ }^{1}$, chromium polynicotinate ${ }^{2}$, chromium propionate ${ }^{3}$ etc are commercially popular variants of $\mathrm{Cr}(\mathrm{III})$ which are used to cure chromium deficiency which causes malfunctioning of hormones like insulin ${ }^{2}$. A large number of organic variants of chromium(VI) like Collin's reagent ${ }^{4}$ pyridinium chlorochromate ${ }^{5}$, pyridinium fluorochromate $^{6}$ etc. have been reported as potent oxidants for different classes of organic substrates. The study of redox processes involving chromium(VI) variants and biologically active substrates like carbohydrates and amino acids etc. may give us a clue to understand the role of chromium(III) in biological processes as well as to get rid of toxic chromium(VI) from the body. Chromium(III) forms complexes with amino acids as ligand ${ }^{7,8}$. Khade et.al., ${ }^{9}$ has reported the preparation and stability of chromium complexes with drug salbutamol and amino acids. Luo et al., ${ }^{10}$ have made a detailed study of relative sorption of organic complexes of $\mathrm{Cr}$ (III) like its glutamate, oxalate, citrate, pyruvate etc. The complexes of chromium with naturally occurring amino acid have been reported by Shahawi ${ }^{11}$. 
In order to explore the possibility of formation of $\mathrm{Cr}$ (III) complexes with biologically significant organic compounds, we have prepared a large number of products by the interaction of di-tertiary butyl chromate with carbohydrates and amino acids under microwave irradiation condition. Microwave assisted organic synthesis involving oxidation of organic substrates by di-tertiary butyl chromate has been reported ${ }^{12}$. In this paper, we report the preparation and characterization of six products of different colour and composition formed by the interaction of di-tertiary butyl chromate (TBC) with sucrose in water and dimethylformamide as solvents.

\section{Experimental}

All the chemicals used in this work were of A.R grade.

\section{Preparation of TBC}

The oxidant TBC was prepared by dissolving accurately weighed amount of dry and powdered chromium trioxide in $10 \mathrm{~mL}$ of $t$-butyl alcohol. The clear brown solution obtained after decantation and filtration.

\section{Preparation of solution of sucrose}

Accurately weighed amounts of pure sucrose required for different substrate- oxidant molar ratio were dissolved in $10 \mathrm{~mL}$ of water and the same procedure was repeated in DMF as solvent. The substrate-oxidant molar ratio (S:O) taken in water as well as DMF were 1:1, 2:1 and 3:1. For 1:1 molar ratio the amount of sucrose and $\mathrm{CrO}_{3}$ taken were $3.42 \mathrm{~g}$ and $1 \mathrm{~g}$ respectively. Similarly for 2:1 molar ratio, the amounts were $6.84 \mathrm{~g}$ and $1 \mathrm{~g}$ and for $3: 1$ the amount of sucrose and $\mathrm{CrO}_{3}$ were $10.26 \mathrm{~g}$ and $1 \mathrm{~g}$ respectively.

\section{Reaction between substrate solution and TBC}

The two solutions were mixed, stirred, heated and then subjected to microwave irradiation before allowing to stand for the period specified in Table 1 . The solid product obtained after washing with acetone till colourless washing and filtration was collected in air tight bottles. The three samples in water as solvent were SW-11, SW-21 and SW-31 whereas in DMF the samples were SD-11, SD-21and SD-31.

Table 1. Time taken in various processes for different substrate-oxidant molar ratio (S:O)

\begin{tabular}{cccccc}
\hline $\begin{array}{c}\text { Sample } \\
\text { Code }\end{array}$ & $\begin{array}{c}\text { Solvent for } \\
\text { Substrate }\end{array}$ & S:O ratio & $\begin{array}{c}\text { Stirring, } \\
\text { min }\end{array}$ & Irradiation & Left \\
\hline SW-11 & Water & $1: 1$ & 21 & 3 min $(180 \mathrm{~W})$ & 1 day \\
SW-21 & Water & $2: 1$ & 30 & $\begin{array}{c}1.5 \min (180 \mathrm{~W})+1.5 \\
\min (360 \mathrm{~W})\end{array}$ & 1 day \\
SW-31 & Water & $3: 1$ & 30 & 3 min $(180 \mathrm{~W})$ & 7 days \\
SD-11 & DMF & $1: 1$ & 10 & 3 min $(180 \mathrm{~W})$ & 7 days \\
SD-21 & DMF & $2: 1$ & 10 & 3 min $(180 \mathrm{~W})$ & 10 days \\
SD-31 & DMF & $3: 1$ & 5 & 3 min $(180 \mathrm{~W})$ & 10 days \\
\hline
\end{tabular}

Estimation and characterization of the samples

The analysis of the samples was done instrumentally and titrimetrically. Chromium was estimated volumetrically using $\mathrm{K}_{2} \mathrm{~S}_{2} \mathrm{O}_{8}$ (excess), $0.1 \mathrm{~N} \mathrm{~K}_{2} \mathrm{Cr}_{2} \mathrm{O}_{7}$ solution and $0.1 \mathrm{~N}$ Mohr's salt solution. Percentage composition of carbon and hydrogen were estimated using Elemental analyser- Heraeus Vario EL III Carlo Erba-1108. The IR spectrum of the products 
were recorded on a Fourier Transform Infra Red Spectrophotometer- Shimadzu 8201 PC. The TGA/DTA curves of the samples SW-11, SW-31, SD-11 and SD-31 were plotted between temperature range 25 to $700{ }^{\circ} \mathrm{C}$ at the rate of $10^{\circ} \mathrm{C} / \mathrm{min}$ on Perkin Elmer Diamond TG/DTA-Thermal Analyser System. The formulations possible on the basis of these studies are given in Table 2.

Table 2. Characterisation of the products (Products: Sucrose + TBC)

\begin{tabular}{|c|c|c|c|c|}
\hline $\begin{array}{l}\text { Sample } \\
\text { Code }\end{array}$ & Colour & $\begin{array}{l}\text { Solubility } \\
\text { in water }\end{array}$ & $\begin{array}{c}\text { Emperical } \\
\text { Formula }\end{array}$ & Formulation \\
\hline SW-11 & Grey & $\begin{array}{l}\text { Partially } \\
\text { soluble }\end{array}$ & $\begin{array}{c}\mathrm{CrC}_{3} \mathrm{H}_{14} \mathrm{O}_{10} \\
\left(\mathrm{Cr}_{2} \mathrm{C}_{6} \mathrm{H}_{28} \mathrm{O}_{20}\right)\end{array}$ & $\begin{array}{l}\mathrm{Cr}_{2} \mathrm{O}_{3} \cdot \mathrm{HOOC}(\mathrm{CHOH})_{4} \mathrm{COOH} . \\
9 \mathrm{H}_{2} \mathrm{O}\left(\mathrm{Cr}_{2} \mathrm{C}_{6} \mathrm{H}_{28} \mathrm{O}_{20}\right)\end{array}$ \\
\hline SW-21 & $\begin{array}{l}\text { Yellowish } \\
\text { green }\end{array}$ & $\begin{array}{l}\text { Partially } \\
\text { soluble }\end{array}$ & $\mathrm{Cr}_{2} \mathrm{C}_{7} \mathrm{H}_{23} \mathrm{O}_{18}$ & $\begin{array}{l}\mathrm{Cr}_{2} \mathrm{O}_{3} \cdot \mathrm{HOOC}(\mathrm{CHOH})_{4} \mathrm{COOH} . \mathrm{H} \\
\mathrm{COOH} 5 \mathrm{H}_{2} \mathrm{O} .\left(\mathrm{Cr}_{2} \mathrm{C}_{7} \mathrm{H}_{22} \mathrm{O}_{18}\right)\end{array}$ \\
\hline SW-31 & Dark grey & $\begin{array}{l}\text { Partially } \\
\text { soluble }\end{array}$ & $\begin{array}{c}\mathrm{CrC}_{6} \mathrm{H}_{20} \mathrm{O}_{10} \\
\left(\mathrm{Cr}_{2} \mathrm{C}_{12} \mathrm{H}_{40} \mathrm{O}_{20}\right)\end{array}$ & $\begin{array}{l}\mathrm{Cr}_{2} \mathrm{O} . \mathrm{OHC}(\mathrm{CHOH})_{4} \mathrm{CH}_{2} \mathrm{OH} . \mathrm{OH} \\
\mathrm{C}(\mathrm{CHOH})_{2} \mathrm{CH}_{2} \mathrm{OH} . \mathrm{CH}_{2} \mathrm{OHCO} \\
\mathrm{OH} .6 \mathrm{H}_{2} \mathrm{O} .\left(\mathrm{Cr}_{2} \mathrm{C}_{12} \mathrm{H}_{36} \mathrm{O}_{20}\right)\end{array}$ \\
\hline SD-11 & $\begin{array}{l}\text { Bottle } \\
\text { green }\end{array}$ & Insoluble & $\mathrm{CrC}_{6} \mathrm{H}_{24} \mathrm{O}_{10}$ & $\begin{array}{l}\text { CrO.OHC }(\mathrm{CHOH})_{3} \mathrm{CH}_{2} \mathrm{OH} . \mathrm{HC} \\
\mathrm{HO} .3 \mathrm{H}_{2} \mathrm{O}\left(\mathrm{CrC}_{6} \mathrm{H}_{18} \mathrm{O}_{10}\right)\end{array}$ \\
\hline SD-21 & $\begin{array}{l}\text { Light } \\
\text { green }\end{array}$ & $\begin{array}{l}\text { Partially } \\
\text { soluble in } \\
\text { hot water }\end{array}$ & $\begin{array}{c}\mathrm{CrC}_{10} \mathrm{H}_{22} \mathrm{O}_{11} \\
\left(\mathrm{Cr}_{2} \mathrm{C}_{20} \mathrm{H}_{44} \mathrm{O}_{22}\right)\end{array}$ & $\begin{array}{l}2 \mathrm{CrO} .2 \mathrm{OHC}(\mathrm{CHOH})_{4} \mathrm{CH}_{2} \mathrm{OH} .2 \\
\mathrm{OHC}(\mathrm{CHOH})_{2} \mathrm{CH}_{2} \mathrm{OH} . \\
\left(\mathrm{Cr}_{2} \mathrm{C}_{20} \mathrm{H}_{40} \mathrm{O}_{22}\right)\end{array}$ \\
\hline SD-31 & Light grey & Insoluble & $\left.\mathrm{CrC}_{25} \mathrm{H}_{53} \mathrm{O}_{25}\right)$ & $\begin{array}{l}\mathrm{CrO} .4 \mathrm{OHC}(\mathrm{CHOH})_{4} \mathrm{CH}_{2} \mathrm{OH} \\
\left(\mathrm{CrC}_{24} \mathrm{H}_{48} \mathrm{O}_{25}\right)\end{array}$ \\
\hline
\end{tabular}

\section{Results and Discussion}

The observations of methods of preparation, colour and formulations of the products lead to many generalization such as

- Microwave irradiation may be helpful in carrying out synthetic processes which are otherwise very difficult. The yield of products formed by the oxidation of carbohydrates and amino acid under ordinary heating conditions have not been satisfactory ${ }^{7}$.

- The products are formed more efficiently when the solvent for sucrose is water rather than when it is DMF.

- As expected, the formation of product takes more time when the substrate-oxidant ratio is more (Table 1).

- $\quad$ The more stable Cr(III) state in the products is observed in case of water as solvent for substrate. In case of DMF as solvent, chromium is reduced to lower oxidation state i.e. II state.

- The products prepared by using DMF as solvent for substrate are not suitable for human consumption as the oxidation state is not III in them as per formulation.

- Out of SW-11, SW-21 and SW-31, only the sample SW-21 may be more suitable as food supplement as the III oxidation state SW-21 is also supported by its colour yellowish green as compared to SW-11 and SW-31 which are grey and black respectively.

- The extent of oxidation in case of water as solvent increases as the substrate-oxidant ration decrease. SW-11 contains glucaric acid whereas SW-31 contains the less oxidised glucose.

- The extent of oxidation is less in case of DMF as solvent for substrate as substantiated by the absence of acidic groups in the products SD-11, SD-21 as well as SD-31. 
- The samples SW-21 and SW-31 were found to be partially soluble in water. Chromium was found to be present in rice grains kept in the aqueous solution of the two samples for 48 hours.

\section{Acknowledgement}

The authors are thankful to CIF, BIT Mesra, Ranchi for valuable inputs of FTIR curve and TGA/DTA mass loss pattern of the samples.

\section{References}

1. Vincent J B, Sack D A, Roffman M, Finch M and Komorowski J R, Sports Med., 2003, 33(3), 213-230; DOI:10.2165/00007256-200333030-0000

2. Anderson R A, Cheng N, Bryden N A, Marilyn M P, Nanping C, Jiaming C and jinduang F, Diabetes, 1997, 46(1), 1786-1791.

3. Staniek H and Krejpcio Z, Food Chem Toxic., 2009, 47(10), 2673-2678; DOI:10.1016/j.fct.2009.07.035

4. $\quad$ Collins J C, Hess W W and Frank F J, Tetrahedron Lett., 1968, 9(30), 3363-3366; DOI:10.1016/S0040-4039(00)89494-0

5. Corey E J and Suggs J W, Tetrahedron Lett., 1975, 16(31), 2647-2660; DOI:10.1016/S0040-4039(00)75204-X

6. Bhattacharjee M M, Choudhari M K, Dasgupta H S, Roy N and Darlando T K, Synthesis, 1982, 588; DOI:10.1055/s-1982-29872

7. McAuliffe C A, Quagliano J V and Vallzino L M, Inorg Chem., 1969, 5(11), 1996-2003; DOI:10.1021/ic50045a034

8. Madafiglio K, Manning T M, Murdoch C M, Tulip W R, Cooper M K and Hambley T W, Acta Cryst., 1990, 46, 554-561; DOI:10.1107/S0108270189008395

9. Khade B.C; Deore P M and Arbad B R, Pharma Science Monitor, 2011, 2(1), 73-86.

10. Luo Z, Wadhwan A and Bouwer E J, Int J Environ Sci Tech., 2010, 7(1), 1-10; DOI:10.1007/BF03326111

11. Shahawi M E, Transition Met Chem., 1993, 18(4), 385-390; DOI:10.1007/BF00208177

12. Katre S D and Pandey H O, Arch Appl Sci Res., 2013, 5(3), 134-136. 